\title{
Reformed theology in dialogue with a spirituality of creation within the context of religious pluralism in Africa
}

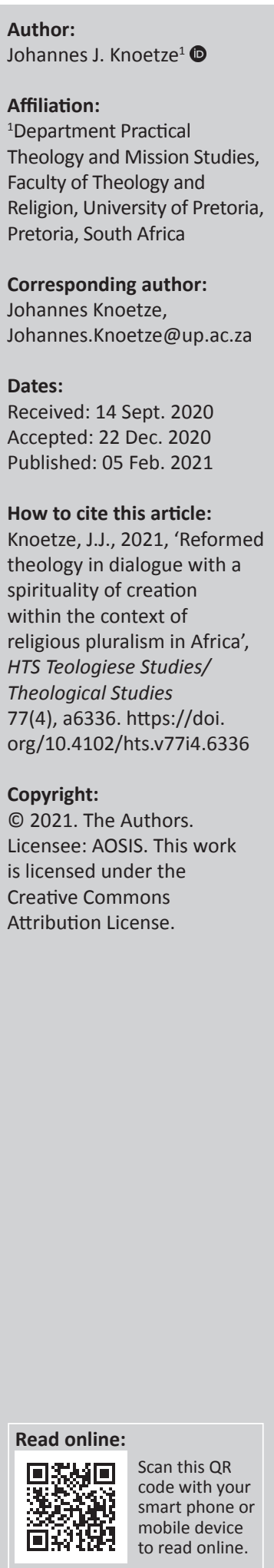

A transforming spirituality is needed to attend to the 'third-millennial needs' of Africa to address issues such as relationships (tribal wars, genocide, ISIS, etc.), globalisation ([new]-colonisation and urbanisation), ecology (industrialisation and rhino or elephant poaching) and social issues (the poor, women and children). It is argued that reformed theology, African spiritualities and a spirituality of creation need to be enriched by each other to bring about transformation in Africa. To discover a transforming spirituality of creation, participants need to listen to the different spiritualities and beliefs, without attempting to create a metanarrative. Participants need to acknowledge the differences and even tensions, and embrace these. As such, this article attends to the research question, how can a dialogue between reformed theology and spirituality of creation help to establish a transforming spirituality based on common values for the diverse African continent in 'our third-millennial world'?

Contribution: From a multidisplinary theological perspective, the article deals with 'historical thought' regarding spirituality and creation. This includes both the textual history from Christianity and oral history from Africa. A missional hermeneutics is used to bring different traditions and beliefs together.

Keywords: reformed theology; African; spirituality; creation; dialogue; third millennial world; transforming.

\section{Introduction ${ }^{1}$}

Psalm 19 reminds us that creation witnesses off God's presence and glory:

${ }^{1}$ The heavens declare the glory of God; the skies proclaim the work of his hands.

${ }^{2}$ Day after day they pour forth speech; night after night they reveal knowledge.

${ }^{3}$ They have no speech, they use no words; no sound is heard from them.

${ }^{4}$ Yet their voice goes out into all the earth, their words to the ends of the world.

In the heavens God has pitched a tent for the sun.

${ }^{5}$ It is like a bridegroom coming out of his chamber,

like a champion rejoicing to run his course.

${ }^{6}$ It rises at one end of the heavensand

makes its circuit to the other;

nothing is deprived of its warmth.

Creation and spirituality are in many instances inseparable and form part of all religions. In the early 1990s, 50 representatives of different religions stated, 'For the first time in history, we have empirical evidence for a common creation story', one of the first steps towards what later became the Earth Charter (Knitter 2000:285). This common creative story of the science creates a new platform from which interreligious dialogue could take place. 'What this common story suggests is that our primary loyalty should be not to nation or religion but to the earth and its Creator (albeit that Creator may be understood in different ways)' (Knitter 2000:286). According to Barry (in Knitter 2000:286), the motivation for this 'primary loyalty' is to respond in a tolerable way to our third millennials world's sensitivities and needs. This means that all religious groups

1.This article was presented at the African Series of International Conference on Spirituality of Creation organised by missio Aachen in conjunction with the commission of Justice and Peace and Integrity of Creation of the Divine Word Missionaries, SVD in Botswana from 7 th to 9th January 2020. 
will take the earth as their primary source of revelation and context of religious experience in spite of their traditional creeds of faith. However, it needs to be noted that 'a common story' does not necessarily include 'a common spirituality'.

\section{Our third-millennium world}

The question we need to ask is what is different in the needs of 'our third-millennium world'? One of the primary needs of 'our third-millennial world' with all its technology and machines, a universal e-world, is the need for good one-on-one contextualised relationships, especially with people, but also with creation and God. The relational need is reflected in different areas of human life such as spirituality, faith, religion, work, ecology and humanity. In a hyper-connected pluralistic world, the question we need to ask is whether it is possible to have, or are we in need of universal stories or meta-narratives? The danger with meta-narratives is the ignorance of language and contexts. Thus, it has all to do with power - the powerful will always determine the meta-narrative. It is best explained in the African proverb: 'Until the lion has his own storyteller, the hunter will always have the best stories'.

Knitter (2000:287) indicates that meta-narratives are restricted by language because we only speak what we know, and our knowledge is determined by the way we speak. Since there is no universal language, people are likely to use (their) language in a way that promotes their own well-being over others, even if they are not aware of this. In intercultural conversations, the language of the one with the economic power will be used. The point I want to make is that the meta-narrative is the narrative of the one with the power. Such a shared creation story for all religions is described by Knitter (2000:287) as a 'divinization of the earth' ${ }^{2}$ based on a 'sacralisation of science', a 'new ecologism' that becomes an 'eco-olatry'. In 'our thirdmillennial world', we do not need meta-narratives, or a further or new dualism between the spiritual and physical, we need shared values. It is then suggested by Knitter and others that to create a common story, we should rather start with ethics/ values than with religion. The main research question of this article is thus, can a dialogue between reformed theology and a spirituality of creation help to establish a transforming spirituality based on common values for the diverse African continent in 'our third-millennial world'?

To answer this question, notice will be taken of the differences between, but also the interrelatedness of theology, religion and spirituality. The article is written from a Reformed perspective and makes use of a missional hermeneutics. The article is structured as follows: First, attention will be given to different understandings of spirituality with a specific focus on African spiritualities ${ }^{3}$ to contextualise the article. Second, an understanding of reformational theology with a

2.Wright (2006:402) states, "There is a fundamental difference between treating creation as sacred and treating it as divine. The sacredness or sanctity of creation speaks of its essential relatedness to God, not of its being divine in and of itself'.

3.This article acknowledges that there are different African spiritualities, but also acknowledges that there are enough similarities amongst them to follow a homogenising system in which there is no room for an in-depth discussion of the unique and complex religious system of each group of people. specific reference to creation will be discussed. Third, the importance of dialogue and the identification of the values or ethics that are important in such a dialogue, especially for the African continent, will then be considered.

\section{Spirituality}

Spirituality is discussed on different forums that are not always religious. Wellman, Perkins and Wellman (2009) define spirituality as follows:

'Spirituality' then is not defined by an explicit set of religious beliefs or practices. On the contrary, spirituality does not need religion at all to define itself ... Spirituality, therefore, is more about how people identify themselves, how they view the world, interact with others and make decisions. (p. 1)

One of the characteristics of a spirituality of creation is that it is not necessarily religious but has more to do with the way in which people identify themselves, and their worldview; this contributes to their understanding of God or a god. One of the main characteristics of spirituality is its concern with the quest for the meaning of life. Schneiders (2005:15) separates 'spirituality' as an academic field from both theology and religious studies, but it is important to acknowledge the interdependency and relatedness of spirituality, theology and religion. It is thus important to realise that when we talk about reformed theology and a spirituality of creation, we are in fact talking about two different, but related, academic fields. Maybe it will be wise to rather talk about reformed ${ }^{4}$ spiritualities, as I assume that there is also not only one spirituality of creation, but different religions have different spiritualities of creation. Waaijman (2002:1) explains 'spirituality' as 'our relationship to the Absolute', whatever the understanding of the Absolute may be. When spirituality involves an explicit reference to God or the Divine, then that spirituality is religious. It is important to note Nürnberger's (2007) remark on religion in this regard:

Religions are not fixed and watertight systems of meaning, but subject to internal change and external impact. Moreover, if genuine, they respond to changing needs and perceptions of reality. Religious assumptions are always in historical flux, integrating elements from outside, reacting to new experiences, producing new intuitions. What matters in particular cases is not the ostensibly 'original' form of an African spirituality, which may or may not have been practised centuries ago, but its present, living form. (p. 35)

Related to the above, and according to Kourie (2010:19), everybody owns a spirituality which determines the ultimate purpose of their being. When a particular group agrees to common values and traditions whether religious or not, it might be referred to as the spirituality of the group. It is thus, for example, possible to speak of 'atheist' spirituality as well. On an academic level, spirituality is the discipline 'which studies the lived communal and individual experience of that - energy, power, or force' (Gumo et al. 2012:524), which gives meaning to life for a specific people.

In light of the above understandings, the dialogue between reformed theology and a spirituality of creation will focus 4. Reformed in this instance means to always go back to the Bible to observe the way in which the Trinitarian God was worshipped. 
more specifically on Africa and African spiritualities/ understandings of creation. From an African perspective, it is imperative to understand that spirituality (in general) is more relational and cultural than religious, 'the nature of God in Africa is neither homogeneous nor an expression of a people's relationship with Him' (Gumo et al. 2012:525). Mbiti (2015:615) argues that factors such as geographical location, culture, language, as well as social and political factors directly influence people's understanding in relation to the African traditional concept of God. Indigenous African spiritualities are based on various African worldviews which are formed through values, rituals, traditions, culture, beliefs and language. However, different African spiritualities have developed in hybrid with mainly Christianity, Islam and modernity, although traditional Africa beliefs continue to influence the lives of many Africans - of which some are highly educated, some are confessed Christians and others confessed Muslims (Gumo et al. 2012:524). Most Africans actively exercise their African spirituality in their daily lives, whether working the fields, attending a beer party or even a funeral ceremony, and in the modern world, they take their spirituality with them to industry, university and parliament. In discussing African spirituality, Edwards (2012:50) refers to 'the experience of spirit as distinct from "religion," which is generally concerned with systematized forms of spirituality'. Mbiti (1991) clearly indicates the interdependence of traditional African religion to creation in his discussion on topics like the universe (pp. 34-43), and his reference to the 'Nature Spirits' (p. 71), the creation of man (p. 83) and agricultural rituals (p. 134). The author concludes that African spiritualities will be enriched from and contribute towards a spirituality of creation.

\section{A spirituality of creation}

Spirituality is defined as a universal, multidimensional experienced phenomenon consisting of the following interrelated domains: (1) higher or universal power, (2) self-discovery, (3) relationships and (4) eco-awareness (Knoetze 2014:174). Thus, true spirituality is not a pie-in-the-sky dream, it does not withdraw people from the realities of the world; it is not an escape from reality, but rather an engagement with reality and creation (Knoetze 2019:3). Since creation is always closely linked to God or a god, a spirituality of creation must invite all people to respond to God's presence in the world around us (Classen 2008:77). Biblical passages such as Job 12:7-10 remind us that creation naturally knows something that we as humans still need to learn that 'in [God's] hand is the life of every creature and the breath of all mankind':

${ }^{7}$ But ask the animals, and they will teach you, or the birds in the sky, and they will tell you; ${ }^{8}$ or speak to the earth, and it will teach you, or let the fish in the sea inform you. ${ }^{9}$ Which of all these does not know that the hand of the Lord has done this? ${ }^{10}$ In his hand is the life of every creature and the breath of all mankind.

A spirituality of creation recognises creation as a reflection of the Creator. God's Spirit is present in all that exists, caring for us and teaching us how to live in harmony (Classen 2008:76). This corresponds with various African spiritualities. Africa understands that humans live in a religious and spiritual universe so that natural phenomena and objects are intimately associated with God (Gumo et al. 2012:525). Creation does not only originate from God but also bears witness to him. Our understanding of creation, and in the end, of God, is and will be strongly coloured by the context in which we live. It can be accepted that a person who grew up in a flat in the inner-city of Europe will have a totally different perception or experience of God than someone who grew up in a rural area in Africa, and will therefore also have a different spirituality of creation. Thus, although creation is sacred and gives us an awareness of God, it will not be proper to worship it, and it will also not be possible to completely know God from creation because God is much more than our experiences, perceptions and expectations. God is the wholly other. Traditionally, Africans see in creation not only the presence but also 'the reflection of God; and whether that image is marred or clearly focused and defined, is nevertheless an image of God, the only image known in traditional African societies' (Gumo et al. 2012:525). It is in this regard that we need to take the fundamental difference between the sacred and the divine seriously, as described by Wright (2006:402). He acknowledges that there is a sacredness about the created world which we need to honour, 'but to worship nature in any of its manifestations is to exchange the Creator for the created'. A clear distinction needs to be made between 'nature' and 'creature'. Whilst 'nature' refers to the world around us, 'the biblical term "creature" points to the truth of our total dependence on God' (Link 2004:128).

\section{Reformed theology}

Reformed theology is Trinitarian theology and adheres to the following characteristics: biblical, systematic, contextual, contemporary and practical (Erickson 2001:16). Reformed theology developed from a specific context broadly described as 'Christendom', but which no longer exists. Therefore, the historical reformed confessions, like the Canons of Dordrecht and the Heidelberg Catechism focused almost entirely on differentiating Protestant, Reformed Christianity from other Christian churches, and therefore did not attend to particular elements such as a pluralistic religious worldview (Logan 2017:5-6). Although there are many ways in which to describe reformed theology, the most well-known way is to describe it according to the five solas: sola Scriptura [according to Scripture alone], sola gratia [saved by grace alone], sola Christus [in Christ alone], sola fide, [through faith alone] and Soli Deo gloria [for the glory of God alone]. What is important is not only to take note of these five solas but also how they relate and are interdependent of each other. A further important aspect of the five solas would be to deconstruct them, but this is beyond the scope of this article. The interdependence and the deconstruction of the five solas become even more important when we talk about a Reformed spirituality amongst the vast plethora of spiritualities in a pluralistic Africa.

5.Discussing Reformed theology, this article follows a homogenising system in which there is no room for an in-depth discussion of the unique and complex there is no room for an in-depth discussion of the unique and complex
differentiations in Reformed theology. It is the deliberate intention of the article to differentiations in Reformed
be as inclusive as possible. 
Within the context of understanding theology in a pluralistic world, Bosch (1991:484) refers to six formative factors: 'experience, revelation, Scripture, tradition, culture, and reason', later followed by a seventh formative factor, namely, 'another religion'. Painfully aware of the power hidden in biblical fundamentalism as used by conservative evangelicals (Knitter 1990:75-95), as well as the misuse of God's name in history and today, the author wants to describe reformed or rather reformational theology within the context of a pluralistic religious and spiritual world from a missional hermeneutical understanding. ' ... a missional hermeneutic must include at least this recognition - the multiplicity of perspectives and contexts from which and within which people read the biblical texts' (Wright 2006:39). Thus, a missional hermeneutics that will take into account the multiplicity of perspectives and context of reformed theology in Africa, and a spirituality of creation are essential if we want to enter into a dialogue.

A missional hermeneutical understanding of sola Scriptura (according to Scripture alone), implies that the whole Bible constitutes the coherent revelation of the mission of God, [and as Christians] we find our whole worldview impacted by this vision' (Wright 2017:x). A reformational understanding of creation is that God created ex nihilo, and he is therefore totally different from creation or any creature. Although human beings are unique amongst all of God's creatures, they are part of the whole creation. The unique ministry/ service of human beings is exercised within the community of all creatures. It is also important to realise that God also acts through the soil: 'Let the earth bring forth plants' (Vischer 2004:14). Luther therefore sees Creation primarily 'from the side of God's perpetual struggle against the "nothing" threatening the existence of the world and calling into question the superior power of God' (in Link 2004:129). In a highly engaged globalised world, the threat for creation and creatures is to be 'nothing' or at most consumables for the sake of 'development'; this is slightly different from Luther but essentially it comes to the quest for meaning. Other than Luther, the core of Calvin's theology is the glory of God who has created everything to be the 'theatre of his glory'. But creation is not only the stage of his glory but also the performance of his glory.

In the New Testament, God the Creator reveals himself in the incarnation of Jesus Christ. 'Jesus introduces no new God' (Vischer 2004:18). According to the book of Hebrews in Scripture, Jesus is the complete (visible) revelation of the (invisible) God. In reformed theology, creation and incarnation may never be separated. Scripture makes it clear that like creation, salvation and mission belong to God (Wright 2017:x) and find fulfilment in the incarnation of Christ. Central to Calvin's understanding of Creation is the significance of the divine logos. 'By the word (logos) of the Lord the heavens were made, their starry host by the breath of his mouth' (Ps 33:6). 'In the beginning was the Word (logos), and the Word was with God, and the Word was God. He was with God in the beginning. Through him all things were made; without him nothing was made that has been made' (Jn 1:1-3). God also created the church through the incarnation of Jesus Christ (the logos) for his mission (the logos) in the world, as part of the performance of his glory (2 Cor 2:14-17). The church has the privilege of participating in the missio Dei, which brings us to sola gratia (saved by grace alone).

Wright (2006:397-399) argues that the main message of Genesis $1-2$ is the fact that creation is good, and that a good creation can only be the work of a good God. He comes to the conclusion that creation is not only valuable to humans, but humans are valuable because we are part of creation. Thus, understanding sin as corruptio totalis as formulated by the Synod of Dort means that all humans are equal before God. From this point of nothing to offer to God, again at ex nihilo, we can understand the incarnation and salvation as sola gratia, in the same way, we understand creation from the perspective of creation ex nihilo. Understanding the sola gratia, we may read every part of the Bible in the light of God's calling to participate in the missio Dei so that he may be glorified through all Creation. This includes the whole community of believers, from the Jews and the Gentiles to the extended community of the covenant with Abraham, who is called as the agent of God's blessing to the nations in the name and to the glory of the Lord Jesus Christ. Such a reading implies that we no longer ask, what is God's calling for my life, but rather, where does my life fit into God's story, or into God's creation? The Genesis 1 story, actually, the whole of the Old Testament, does not offer a theory on the origin of the world or the purpose of human life but rather invites Israel/believers to respond in faith to the creating powers of God (Vischer 2004:14). This brings us to ask, what is the meaning of salvation, and what does it entail? As such, God's covenant has a cosmic nature and finds expression in the gift of the land. People are called to praise and obey God in their caring of the land. The laws of the Sabbath and the Jubilee are especially important in this regard, and its celebration has important implications for the relationship of human beings to the rest of creation. One of the most important aspects of the Sabbath and the Jubilee is its reference to the restoration of justice amongst the people and the fertility of the soil (Vischer 2004:17; Wright 2006:289-323).

From the above, the interdependence of sola gratia on sola Christus [in Christ alone] is clear. Sola Christus implies that the life of Jesus of Nazareth will be central to our understanding of the messianic (salvific) identity founded in his cross and his resurrection, as well as his mission to the Old Testament Israel and to the nations. According to reformed theology, Jesus is also the complete revelation of God. The sola Christus is described by John as the logos (refer to the discussion above), whilst he is described in creational terms by Paul when the mission of God is described as the unification of all creation under Christ (Eph 1:9-10) and to reconcile all of creation through the cross and the resurrection of Christ (Col 1:15-20). An important eschatological implication of sola Christus is that the whole of creation - all creatures, even things without a soul - is awaiting the renewal of Christ 'to bring back everything to its true condition and order' (Link 2004:131). Link (2004:132-134) also highlights the important 
contribution of Moltmann to creation theology when he talks about 'Creation in the Spirit'. This indicates that God is not only the cause of creation, but he remains present in creation and as such maintains the radical immanence of God, in the here and now. The immanence of God will only be a reality through faith.

The sola fide - through faith alone understanding of the Bible - means that we no longer talk about applying the Bible to our lives, but 'instead apply our lives to the Bible, assuming the Bible to be reality - the real story to which we are called to conform ourselves' (Wright 2017:xi). The importance of this for a spirituality of creation is that we no longer adjust creation to fit our lives, but we adjust our lives to fit into creation. We will no longer be driven by a tailor-made purpose for our lives but will realise that the purpose of all life, including ourselves, is enclosed in God's creation and in the mission of God for the whole of creation. It should be clear that all four of the above-mentioned solas focussed on the Soli Deo gloria [for the glory of God alone]. Again, this was already discussed when Calvin argued that the core of reformed theology is the glory of God.

\section{Dialogue}

The method in which reformed theology engages with a spirituality of creation in a pluralistic religious world must be in the form of a dialogue. Dialogue creates the space to listen to others and become visible in a meeting of the hearts rather than the minds because it deals with a mystery. Bosch (1991:483-489) describes some characteristics of such a dialogue. The first is the heart's decision to accept the coexistence of different faiths, beliefs or convictions. The second is the true dialogue which presupposes commitment. Through listening to other faiths, beliefs or convictions, we witness to our own faith, belief and conviction. 'It is a false construct to suggest that a commitment to dialogue is incompatible with a confessional position' (1991:484). Thus, no one enters into a dialogue as a clean slate, everybody has beliefs and convictions from where he or she participates in the dialogue. Third, dialogue about faiths, beliefs and convictions does not happen in a void, but with the expectation to meet the God who has gone before us, preparing all the participants within their own contexts, beliefs and cultures. In a dialogue, there are no 'haves' over the 'have nots', because it reaches beyond the claim of any absolutes or meta-narratives and happens within the context of a creative tension. Therefore, in the fourth place, dialogue can only happen with an attitude of humility. Reformed Christians should even be more aware of their vulnerability, because they confess the sola gratia - the grace of God - which is freely given, and they confess that all of us find ourselves at the foot of the cross, corruptio totalis, which also judges Reformed Christianity. Fifth, in dialogue with people from other faiths, beliefs and convictions, we need to recognise that faiths, beliefs and convictions create their own worlds with their own structures, which might point in different directions and ask profoundly different questions. A sixth characteristic of dialogue is that it is not a substitute for mission. Mission and dialogue are neither identical nor opposed to each other. 'We affirm that witness does not preclude dialogue but invites it, and that dialogue does not preclude witness but extends and deepens it' (1991:487). Christian faith can never deny that God, because he loves the cosmos/world, sent Jesus Christ into this world (Jn 3:16) to give new life to people and an eschatological hope for creation ( $\mathrm{Rm}$ 8:18-25). God's action expects a reaction; he therefore sent his Spirit to call humans to provoke a response of conversion. Therefore, the seventh characteristic of dialogue is that it does not leave us unchanged; it calls for action. From a Christian perspective, it calls for conversion, and although we know it creates tension between different faiths, 'We appreciate this tension and do not attempt to resolve it' (1991). As Reformed Christians, we enter into dialogue with:

A bold humility - or a humble boldness. We know only in part, but we do know. And we believe that the faith we profess is both true and just and should be proclaimed. We do this, however, not as judges or lawyers, but as witnesses; not as soldiers, but as envoys of peace; not as high-pressure sales persons, but as ambassadors of the Servant Lord. (p. 489)

Dialogue is an inclusive method that creates space for open participation in cooperative sharing of beliefs and convictions. The purpose and objective of the dialogue between reformed theology and a spirituality of creation are to listen together from different perspectives so that we may participate in the liberation of creation from deterioration:

For the creation was subjected to frustration, not by its own choice, but by the will of the one who subjected it, in hope that the creation itself will be liberated from its bondage to decay and brought into the freedom and glory of the children of God. (Rm 8:20-21)

One of the best examples of the impact of dialogue between reformed theology and African spiritualities is found in the book African Earthkeepers, by Daneel (1998).

\section{Important values for a dialogue on transforming a spirituality of creation}

Before any values for a dialogue can be discussed, the purpose of the dialogue needs to be determined along with the importance for participants. The purpose of the proposed dialogue is to develop or rather discover a transforming spirituality of creation. It is acknowledged that it is a bit ambiguous to talk about a transforming spirituality of creation. 'Transforming' can be read as an adjective describing 'a spirituality of creation'. Read as an adjective, a spirituality of creation is understood as the enterprise that transforms our reality. However, 'transforming' can also refer to the activity of transforming when it is read as a present participle; in this case, the transforming of a spirituality of creation. Spirituality of creation is then not the enterprise that transforms reality, but something that is itself being transformed. The ambiguity of the purpose of 'transforming a spirituality of 
creation' is deliberate because the author is convinced that this duality is important and necessary. For too long, discussions about creation were divided between science and religion because we were looking for one meta-narrative. It is also clear that neither science nor religion (reformed theology or African traditional beliefs) can solve the ecological challenges we face in 'our thirdmillennial world'. Therefore, a 'spirituality of creation' needs to be inter- and intra-disciplinary, and inter- and intra-religious.

The reason for this article to focus only on reformed theology and African spiritualities of Creation is contextual. Reformed theology in Africa shows little evidence of devoting energy to the ecological questions of a 'thirdmillennial Africa'. There might be three broad reasons for this. First, the ecological impact on 'third-millennial Africa' was not prioritised by reformed theology in Africa within a plurality of spiritualities. Second, as a theology from the West, reformed theology has been relegated to the private realm of spiritual things and has therefore insufficiently attended to social, economic or ecological matters. Third, with the aftermath of the mission era, the 'missionary, go home!' outcry of 1970s, the colonial and apartheid history, and the rise of African Independent Churches and Pentecostalism in Africa, reformed theology might have lost its nerve a little bit. We are not sure if we are worthy of a place at the table in assessing and engaging in a spirituality of creation. In the same way, African spiritualities show little evidence of devoting energy to the ecological questions of a 'third-millennial Africa', although creation is central to these spiritualities. Possible reasons for their apathetic approach may be because of Africa's holistic view on life and that both the positives and negatives of colonisation and globalisation were never considered a threat to African spirituality.

One may then ask, why is a dialogue between reformed theology and a spirituality of creation necessary and important for Africa? There are many reasons. First, like colonisation, globalisation, tribal wars and natural disasters, an emergent ecological and social crisis is transpiring on the African continent. Africa is in need of a transforming spirituality of creation which neither reformed theology nor African spiritualities have on their own. Second, some of the poorest of the poor live on the African continent and they survive on what creation provides. A shared concern for the poor and the creation is needed between globalisation, religion and tradition. Third, to date, both reformed theology and a spirituality of creation have failed in three critical areas: (1) the understanding of human beings was either reductionist or exaggerated, which resulted in a crisis of meaning because of different understandings of sin; (2) the role and purpose of power has been (mis)used in both reformed theology as practised in Africa and spiritualities of creation and (3) both reformed theology (because it was not contextualised to address the spiritual needs of Africa) as well as African spiritualities (because it was more cultural and traditional) have failed to provide spiritual and ethical structures to enable 'third-millennial Africans' to realise their true identity (who they are), calling (why they are here) and purpose (how they should be here). The final argument for the importance of such a dialogue is the important contributions that reformed theology and African spiritualities can and must make towards a transforming spirituality of creation. To this, I now turn my attention.

The following values for a dialogue between reformed theology and a spirituality of creation are proposed from a reformed perspective for a transformational spirituality of creation within the African context, although it might also have universal value. Engaging with the principles for a dialogue as discussed above, the following six values are proposed:

- Openness - to accept the coexistence of different faiths, beliefs or convictions about creation.

- Commitment - to listen to and learn from other faiths, beliefs or convictions whilst we witness to our own faith, belief and conviction. Since no one enters into the dialogue as a clean slate, it is the only way we can contribute to a transforming spirituality of creation, when we ourselves are willing to be transformed.

- Equality - there may be no power positions. No 'haves' over the 'have nots'. This has implications for the language used, and context, the place (building) where the dialogue is taking place. In reformed language, we are all equal because of our corruptio totalis and the sola gratia.

- Compassion - a true compassion for creation on the continent of Africa and the people of Africa, and not in the first place for our own views and or religions, but a search for meaning.

- Acknowledgement of tension - in the dialogue in search of a transformational spirituality of creation, we may not deny the obvious tensions between different beliefs and views. We acknowledge that all participants also have secondary motives for participation, but nevertheless, let us embrace these differences and tensions and not attempt to resolve them. This is part of the mystery of a transforming spirituality of creation.

- Response - a transforming spirituality of creation would expect a response from each participant, whether it is a totally new identity, calling or purpose.

A dialogue as suggested here is very contextual and location-based. As in the example of Daneel (1998), it boils down to personal relationships between leaders - church leaders and traditional leaders in Africa - in a specific area. As such, it is a bottom-up approach and when implemented successfully, it will grow from one geographical area to the next. Since the transformational aspect relies on personal relationships and different contexts and needs, there is no blueprint but to keep to the agreed values for the co-operation to bring about transformation. 


\section{Conclusion}

This article addressed the research question, how can a dialogue between reformed theology and a spirituality of creation help to establish a transforming spirituality based on common values for the diverse African continent in 'our third-millennial world'? Having discussed the relevant themes in the question, the article proposes the need for a transforming spirituality of creation in Africa. A transforming spirituality is needed to attend to the 'third-millennial needs' of Africa to address issues such as relationships (tribal wars, genocide, ISIS, etc.), globalisation ([new]-colonisation and urbanisation), ecology (industrialisation and rhino or elephant poaching) and social issues (the poor, women and children). It is argued that reformed theology, African spiritualities and a spirituality of creation need to be enriched by each other to bring about transformation in Africa. To discover a transforming spirituality of creation, participants need to listen to the various spiritualities and beliefs, without attempting to create a meta-narrative. Participants need to acknowledge the differences and even tensions, and embrace it. This will only be possible if participants agree to at least the six proposed values: openness, commitment, equality, compassion, acknowledgement of tension and response.

\section{Acknowledgements Competing interests}

The author has declared that no competing interest exists.

\section{Authors' contribution}

J.J.K. is the sole author of this research article.

\section{Ethical considerations}

This article followed all ethical standards for a research without direct contact with human or animal subjects.

\section{Funding information}

This research received no specific grant from any funding agency in the public, commercial or not-for-profit sectors.

\section{Data availability}

Data sharing is not applicable to this article as no new data were created or analysed in this study.

\section{Disclaimer}

The views and opinions expressed in this article are those of the author and do not necessarily reflect the official policy or position of any affiliated agency of the author.

\section{References}

Bosch, D.J, 1991, Transforming mission: Paradigm shifts in theology of mission, Orbis Books, Maryknoll, New York, NY.

Classen, S., 2008, 'A spirituality of creation care', Vision 9(1), 76-83.

Daneel, M.L., 1998, African Eartkeepers: Interfaith mission in earth care, UNISA Press, Pretoria.

Edwards, S.D., 2012, 'The effect of African breath psychotherapeutic workshops on spirituality perceptions and experiences', Indilinga-African Journal of Indigenous Knowledge Systems 11(1), 49-60.

Erickson, M.J., 2001, Introducing Christian doctrine, Baker Academic, Grand Rapids, MI.

Gumo, S., Gisege, S.O., Raballah, E. \& Ouma, C., 2012, 'Communicating African spirituality through ecology: Challenges and prospects for the 21st century', Religions 3(2), 523-543. https://doi.org/10.3390/rel3020523

Knitter, P.F., 1990, No other name? A critical survey of Christian attitudes toward the world religions, Orbis Books, Maryknoll, New York, NY.

Knitter, P.F., 2000, 'A common creation story? Interreligious dialogue and ecology', Journal of Ecumenical Studies 37(3-4), 285-300.

Knoetze, J.J., 2014, 'Transforming a fragmented South African society through a spirituality of koinonia coram Deo', Nederduitse Gereformeerde Teologiese Tydskrif (NGTT) 55(1), 167-187. https://doi.org/10.5952/55-1-2-520

Knoetze, J.J., 2019, 'African spiritual phenomena and the probable influence on African families', In die Skriflig/In Luce Verbi 53(4), a2505. https://doi.org/10.4102/ ids.v53i4.2505

Kourie, C., 2010, 'Teaching spirituality at Unisa: 2000-2010: Some reflections', Missionalia 38(1), 17-31.

Link, C., 2004, 'Creation theology, a protestant perspective', in L. Vischer (ed.), Listening to creation groaning, pp. 128-147, John Knox, Geneva.

Logan, S.T., 2017, 'Why the World Reformed Fellowship seeks to encourage missional theology and practice', in S.T. Logan (ed.), Reformed means missional: Following Jesus into the world, pp. 1-8, New Growth Press, Greensboro, NC.

Mbiti, J.S., 1991, African religion and philosophy, 2nd edn., Heinemann, Nairobi.

Mbiti, J.S., 2015, African religions and philosophy analysis, E-notes, viewed 12 November 2015, from http://www.enotes.com/topics/african-religionsphilosophy.

Nürnberger, K., 2007, The living dead and the living God: Christ and the ancestors in a changing Africa, Cluster Publications, Pietermaritzburg.

Schneiders, S.M., 2005, 'Approaches to the study of Christian spirituality', in A. Holder (ed.), The Blackwell companion to Christian spirituality, pp. 15-33, Blackwell, Malden, MA.

Vischer, L. (ed.), 2004, Listening to creation groaning: Report and papers from a consultation on creation theology organised by the European Christian Environmental Network at the John Knox International Reformed Center from March 28 to April 01 2004, Center International Réformé John Knox, Geneva.

Waaijman, K., 2002, Spirituality: Forms, foundations, methods, Peeters, Leuven.

Wellman, W., Perkins, G. \& Wellman, N., 2009, 'Educational leadership: The relationship between spirituality and leadership practices', Spirituality in Higher Education Newsletter 7(1), 1-6.

Wright, C.J.H., 2006, The mission of God: Unlocking the Bible's grand narrative, InterVarsity Press, Downers Grove, IL.

Wright, C.J.H., 2017, 'What do we mean by “missional"?', in S.T. Logan (ed.), Reformed means missional: Following Jesus into the world, pp. 9-13, New Growth Press, Greensboro, NC. 